\title{
Effectiveness of Upper Limb Wearable Technology for Improving Activity and Participation in Adult Stroke Survivors: Systematic Review
}

Jack Parker ${ }^{1}, \mathrm{BSc}, \mathrm{PhD}$; Lauren Powell², MSc, BSc (Hons); Susan Mawson ${ }^{2}, \mathrm{BSc}$ (Hons), MCSP, PhD

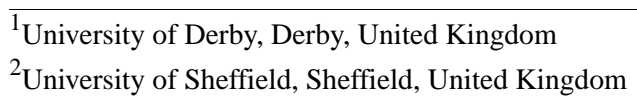

Corresponding Author:

Lauren Powell, MSc, BSc (Hons)

University of Sheffield

Western Bank

Sheffield, S10 2TN

United Kingdom

Phone: 4401142228179

Email: 1.a.powell@ sheffield.ac.uk

\section{Abstract}

Background: With advances in technology, the adoption of wearable devices has become a viable adjunct in poststroke rehabilitation. Upper limb (UL) impairment affects up to $77 \%$ of stroke survivors impacting on their ability to carry out everyday activities. However, despite an increase in research exploring these devices for UL rehabilitation, little is known of their effectiveness.

Objective: This review aimed to assess the effectiveness of UL wearable technology for improving activity and participation in adult stroke survivors.

Methods: Randomized controlled trials (RCTs) and randomized comparable trials of UL wearable technology for poststroke rehabilitation were included. Primary outcome measures were validated measures of activity and participation as defined by the International Classification of Functioning, Disability, and Health. Databases searched were MEDLINE, Web of Science (Core collection), CINAHL, and the Cochrane Library. The Cochrane Risk of Bias Tool was used to assess the methodological quality of the RCTs and the Downs and Black Instrument for the quality of non RCTs.

Results: In the review, we included 11 studies with collectively 354 participants at baseline and 323 participants at final follow-up including control groups and participants poststroke. Participants' stroke type and severity varied. Only 1 study found significant between-group differences for systems functioning and activity $(P \leq .02)$. The 11 included studies in this review had small sample sizes ranging from 5 to 99 participants at an average (mean) age of 57 years.

Conclusions: This review has highlighted a number of reasons for insignificant findings in this area including low sample sizes and the appropriateness of the methodology for complex interventions. However, technology has the potential to measure outcomes, provide feedback, and engage users outside of clinical sessions. This could provide a platform for motivating stroke survivors to carry out more rehabilitation in the absence of a therapist, which could maximize recovery.

Trial Registration: PROSPERO CRD42017057715; https://www.crd.york.ac.uk/prospero/display_record.php?RecordID=57715

(J Med Internet Res 2020;22(1):e15981) doi: 10.2196/15981

\section{KEYWORDS}

wearable electronic devices; stroke; rehabilitation; upper extremity 


\section{Introduction}

\section{Background}

Stroke is a leading cause of mortality and disability worldwide [1], and the economic costs of treatment and poststroke care result in a mean cost to the economy of $£ 46,039$ a year per patient for the first 5 years after admission in England, Wales, and Northern Ireland alone [2]. Following a stroke, survivors are left with multiple impairments, and as a result only $5 \%$ to $20 \%$ will regain full function of the upper limb (UL) with up to $66 \%$ still being impaired in the chronic phase [3]. This often results in functional limitations in activities of daily living and decreased quality of life [4].

Over recent years, there has been a contextual shift in service delivery from hospital-based rehabilitation to the community. Although it has been recommended that rehabilitation should continue until maximum recovery has been achieved [5], owing to the increasing demand on services and financial constraints, service needs cannot be met; therefore, radical innovation and the adoption of a self-management paradigm are considered as a way of delivering independent home-based rehabilitation, thereby meeting the challenges faced in health care [6].

Evidence exists supporting the need for intensity and repetition of motor skills to promote neuroplasticity and motor relearning. With significant advances in information and communication technology (ICT) and more specifically in the rapid development and deployment of sensor technology for health care monitoring, a number of technological aids with a potential to measure and monitor poststroke activity have been explored for both the lower limb [7] and the UL [8]. However, many include the use of expensive, large, complex, ungainly equipment that is impractical to use in everyday contexts [9]. Therefore inexpensive, wearable, and commercially available sensors have become a more viable option for quantifying movements and activities during poststroke rehabilitation [10-12].

A number of recent systematic and nonsystematic reviews highlight the growing use of wearable devices to provide poststroke rehabilitation in both clinical and nonclinical settings for motion analysis and physical activity monitoring [12-17]. These include microelectromechanical systems containing accelerometers, gyroscopes, and magnetometers; fabric and body-worn sensor networks [18], pressure sensors [19-22], and physiological monitoring such as blood pressure and oxygen saturation [23,24]. Other wearable devices specifically designed and used for poststroke rehabilitation also include robotics [25], virtual reality [26], functional electrical stimulation (FES) [27,28], electromyographic biofeedback [29], and transcutaneous electrical nerve stimulation [30-32].

However, while these devices have the potential to reliably measure duration, frequency, intensity, and quality of activity and movement, all of which are key variables for poststroke recovery [33], no reviews have synthesized the evidence underpinning the use of these devices for independent poststroke UL rehabilitation. Therefore, the aim of this review will be to explore and examine how effective these medical devices are as interventions for improving the function of the UL in adult stroke survivors.

The International Classification of Functioning, Disability, and Health (ICF) [34] considers the interaction between pathology (body structure and function), impairment (signs and symptoms), activities (functionality), and participation (social integration), and it has now become the main conceptual framework for poststroke rehabilitation $[5,35,36]$.

\section{Objective}

For this review, we focused on the activities and participation domain of the ICF as this would provide an indication of how the interventions have or have not led to functional gains in everyday life.

\section{Methods}

The review protocol was registered on PROSPERO (CRD42017057715). The review was undertaken in accordance with the general principles recommended in the Preferred Reporting Items for Systematic Reviews and Meta-Analyses [37].

\section{Definitions}

Wearable technologies can be subdivided into those operating independently and functioning as central connectors for other devices "and" or "or" information (eg, wrist-worn fitness tracker and smartphone) and those capturing specific actions or executing a measurement (eg, heart rate monitor worn around the chest) offloading to a primary wearable device for analysis [38]. We define a wearable device in the context of poststroke rehabilitation as "a wearable device that is worn externally on the body that is portable (the user is able to wear the device but is free to move around and not fixed to a station) and is able to use the device independently of a therapist."

\section{Search Methods}

As per the Cochrane Handbook [39], the Population Intervention Comparison Outcome Study Design framework helped authors to define the inclusion and exclusion criteria and the search terms of this review. For this review, the population refers to poststroke adults, the intervention to technological interventions for UL rehabilitation in stroke survivors, and included studies included a comparison group and were not limited to randomized controlled trials (RCTs). The outcome focused on activity and participation measures of UL function poststroke. Search terms and databases were selected based on Cochrane literature and institutional information specialist advice.

The following databases were searched from the year 2000 to April 2019: MEDLINE, Web of Science (Core collection), CINAHL, Scopus, and the Cochrane Library. Medical Subject Headings (MeSH) keywords used were cerebrovascular disorders, hemorrhage, cerebral hemorrhage, sensory feedback, motor skills, physical therapy modalities, physical and rehabilitation medicine, exercise, exercise therapy, rehabilitation, exercise movement techniques, information technology, technology, self-help devices, telemedicine, upper extremity, arm, hand joints, shoulder joint, elbow joint, and wrist joint. Text terms used were stroke, UL, rehabilitation, and technology. 
These were combined with the following synonyms: CVA, cerebrovascular accident, poststroke, cerebrovascular, brain ischemia, brain vascular, upper extremity, arm, shoulder, hand, axilla, axilla, elbow, forearm, finger, wrist, physiotherapy, physical therapy, physiatric, exercise, biofeedback, sensory feedback, advise, train, therapy, treat, motor skills, motor relearn, re-educate, recovery, enhance, promote, support, function, activity, physical, information technology, IT, ICT, information and communications technology, assistive technology, telehealth, telecare, telerehabilitation, and wear. Boolean logic was used to combine terms using AND and $O R$. $\mathrm{MeSH}$ terms refer to specific terms that are recognized for indexing journals and books in electronic databases. The free text terms and synonyms were words used in the search strategy that was looked for in titles and abstracts. The MEDLINE search strategy can be found in Multimedia Appendix 1. Electronic citations were downloaded into a reference manager. The inclusion and exclusion criteria for the search strategy are presented in Textboxes 1 and 2, respectively.

As technology is changing very quickly, authors deemed technology before the year 2000 to be particularly outdated. RCTs and randomized comparable trials were chosen as the appropriate study design for inclusion in this review as the review aims to assess the effectiveness of the included interventions. Non-RCT and nonrandomized comparable trial evidence is therefore outside the scope of this review. Comparators (control groups) could include treatment as usual and exercise therapies that do not include any other intervention or sham stimulation.

The primary outcome measures for this review are those that assess activity or participation as defined by the World Health Organization (WHO) ICF [40]. These measures include the following: the Box and Blocks Test (BBT) [41]; Action Research Arm Test (ARAT) [42]; Barthel Index (BI) [43]; Chedoke Arm and Hand Activity Inventory (CAHAI) [44-47]; Jebson-Taylor Hand Function Test (JTHFT) [48]; Wolf Motor Function Test (WMFT) [49]; Motor Activity Log (MAL) [50]; Motor Assessment Scale (MAS) [51]; Stroke Impact Scale (SIS) [52]; the Rivermead Motor Assessment (RMA) [53]; Upper Extremity Function Test (UEFT) [54]; and the short version of disabilities of arm, shoulder, and hand (QuickDASH) [55].

A total of 3 measures of system functioning WHO ICF, namely, the Fugl-Meyer Test [56], the Arm Motor Ability Test [57], and the pain Visual Analogue Scale [58], were not included in this review as the aim was to explore and examine how effective medical devices are used as interventions for improving function (activity and participation) of the UL in adult stroke survivors.

Textbox 1. Inclusion criteria.

- $\quad$ English-language articles

- $\quad$ Studies recruiting people over the age of 18 years

- $\quad$ Studies evaluating upper limb wearable technology

- Studies reporting randomized controlled trials or randomized comparable trials

- Studies measuring activity and or participation as classified by the World Health Organization International Classification of Functioning, Disability, and Health

- Intervention that could be used independently by the stroke survivor

- Wearable and portable technology that measures or monitors activity

- Research article

Textbox 2. Exclusion criteria.

- Non-English-language articles

- Studies recruiting people under the age of 18 years

- Studies not evaluating upper limb wearable technology

- Studies not reporting randomized controlled trials or randomized comparable trials

- Studies not measuring activity and or participation as classified by the World Health Organization International Classification of Functioning, Disability, and Health

- Intervention that could not be used independently by the stroke survivor

- Wearable and portable technology that does not measure or monitors activity

- Not a research article

- Studies where the intervention is not clearly defined (it was unclear to the authors that the study did or did not meet the inclusion/exclusion criteria)

- Study protocols

- Studies reporting a nonwearable, nonportable intervention 


\section{Quality Assessment of Included Studies}

The methodological quality of the included RCTs was assessed using the Cochrane Risk of Bias (CRoB) assessment criteria [59]. This addresses specific fields including sequence generation, allocation concealment, blinding of participants and personnel, blinding of outcome assessment, incomplete outcome data, and selective outcome reporting. RCTs were classed as having an overall low risk of bias if they were rated as low for 3 of the key areas: allocation concealment [60], blinding of outcome assessment, and completeness of outcome data. They were judged as overall high risk of bias if any of these key areas were judged as being an overall high risk. RCTs judged as being at an overall unclear risk of bias were so if any of the 3 areas above were judged as unclear.

For the included non-RCTs, the methodological quality was assessed using the Downs and Black Instrument [61]. This instrument provides a score for each study, and the maximum score is 37 . It assesses the way studies report their findings, their external and internal validity as well as selection bias.

\section{Data Extraction}

The titles, abstracts, and/or papers were screened by the authors LP and JP to find studies that meet the review inclusion criteria. Final papers were decided between the authors JP and LP, and any disagreement was resolved through discussion. A standardized Excel form was used to extract data and study characteristics. This is where information such as data on the interventions and participant characteristics were recorded. The author LP carried out the data extraction and checked for accuracy by the author JP. Whenever applicable, missing data were requested from the authors of the study.

\section{Outcome Measure Quality Assessment}

When undertaking a systematic review, it is important to assess the quality of the outcome measures used in the included studies to ensure that the results are valid and reliable. To achieve this, 3 clear domains can be considered for each of the outcome measures used: (1) whether the psychometric properties of the scale have been assessed previously [62], (2) whether the clinimetric properties of the scale have been considered [63-67], specifically the Minimally Clinically Important Difference (MCID) [66], and (3) whether the statistical analysis of the data provided by the scale fulfills the requirements of measurement theory [68-70].

We identified all outcome measures $(\mathrm{N}=12)$ used in the 11 included studies and reviewed each individually to assess whether they fulfilled the first 2 domains outlined above. The outcome measures measuring activity included BBT [41]; ARAT [42]; BI [43]; CAHAI [44-47]; JTHFT [48]; WMFT [49]; MAL [50]; MAS [51]; RMA [53]; UEFT [54]; and QuickDASH [55]; and the outcome measures measuring participation included SIS [52].

This was determined by reviewing the literature of each of the outcome measures. How the outcome measure was used and how the data were scored and analyzed was then examined for each of the 11 included studies.

All 12 outcome measures were measures of activity $(\mathrm{N}=11)$ or participation $(\mathrm{N}=1)$ as classified by the WHO ICF [40].

\section{Data Synthesis}

A narrative review is presented on the included studies with supporting evidence tables for study characteristics and findings, risk of bias, and outcome measure assessment. A meta-analysis was not undertaken because of the variability of outcome measures used across the 12 included studies.

\section{Appraisal of Evidence}

Studies in this review include RCTs and randomized trials without a control group. The included studies were appraised using the levels of evidence [71]. This is to enhance the understanding of the best levels of evidence included in this review [72]. The highest level of evidence to this end is that of the RCT and is considered to be of level 1 evidence. Randomized trials without a control group are considered to be of level 2 evidence. This is important as the study design can affect the validity and reliability of results. For example, RCTs are often considered the gold standard of research evidence and the most reliable because of the measures taken to reduce the influences of confounds [73].

\section{Results}

\section{Search Results}

The electronic searches identified 2517 citations following deduplication. No additional citations were identified via handpicking methods. Following deduplication, 2517 records were screened and 2445 records were excluded through the title and abstract screening phases. At this stage, 72 full papers were obtained and 61 of these were excluded (reasons for exclusion can be found in Multimedia Appendix 2 [74-132]). Of these, 11 studies reported across 11 publications were included in this review (see Figure 1).

The review included 11 studies carried out in the United States (5), the Netherlands (2), Australia (1), Spain (1), Turkey (1), and Italy (1) with collectively 354 participants at baseline and 323 participants at final follow-up including control groups and participants from 17 days to 5-year poststroke. Of which, 7 studies were RCT level 1 and 4 were level 2 comparison trials and 6 of the 11 studies included acute stroke survivors. Participants' stroke type and severity varied from mild to severe. The interventions used FES (3), a hand device/glove (7), and arm worn garment (1). The duration of the intervention was from 3 to 12 weeks with varying intensity. Only 1 study found significant between-group differences for systems functioning and activity $(P \leq .02)$. The 11 included studies in this review had small sample sizes ranging from 5 to 99 participants at an average (mean) age of 57 years old. 
Figure 1. Article selection. WHO ICF: The World Health Organization International Classification of Functioning, Disability, and Health.

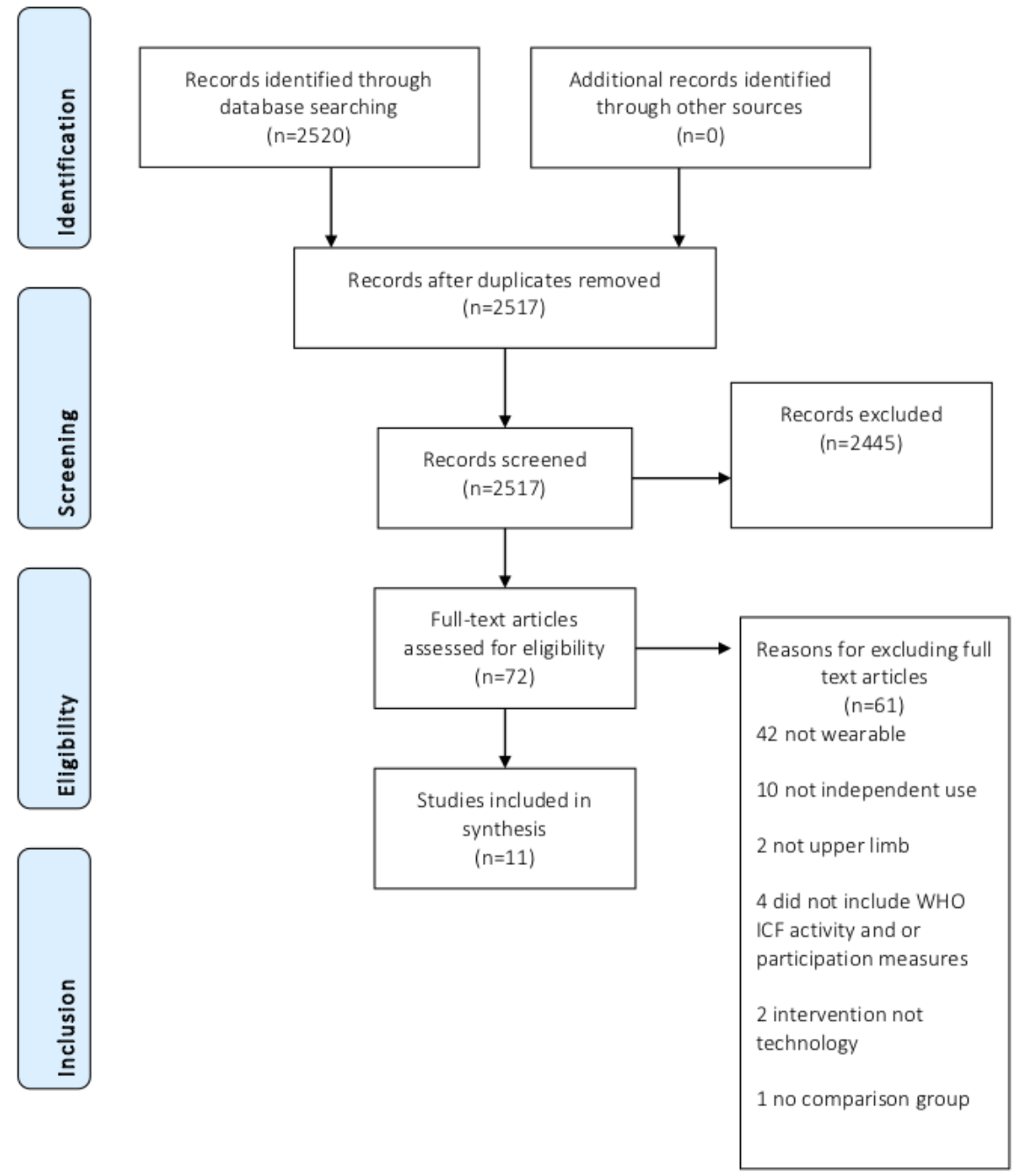

\section{Quality Assessment}

The CRoB quality assessment summary can be found in Table 1 , the Downs and Black quality assessment for non-RCT designs in Table 2 and the outcome measure quality assessment in Multimedia Appendix 3. Full details of the CRoB assessment can be found in Multimedia Appendix 4 and the Downs and Black quality assessment in Multimedia Appendix 5. First, 2 of the 7 included RCTs were judged as having an overall high risk of bias [73]. Of these, 1 of these RCTs was judged to be at high risk of having incomplete outcome data [141], 1 reported outcome assessment was not blinded [142], and 3 did not report blinding of participants and personnel [142-144]. Then, 4 RCTs were judged as having an overall unclear risk of bias [144-147], and 1 of the included RCTs was considered to be at an overall low risk of bias [143].

Non-RCT evidence was assessed using the Downs and Black Instrument, as they were studies that did not involve control groups. Overall, the 4 studies assessed using this instrument received high scores for reporting domains (items 1-10) and internal validity bias (items 14-20). Overall, they obtained lower scores for the external validity (items 11-13), selection bias (items 21-26), and power (item 27). The maximum score that could be obtained from this instrument is 32 . Of the 4 studies assessed using this method, the highest score obtained was 21 [148] and the lowest was 14 [149]. 
Table 1. Cochrane risk of bias quality assessment summary.

\begin{tabular}{|c|c|c|c|c|c|c|c|}
\hline Author, year & $\begin{array}{l}\text { Random se- } \\
\text { quence genera- } \\
\text { tion }\end{array}$ & $\begin{array}{l}\text { Allocation conceal- } \\
\text { ment }\end{array}$ & $\begin{array}{l}\text { Blinding of partic- } \\
\text { ipants and person- } \\
\text { nel }\end{array}$ & $\begin{array}{l}\text { Blinding of out- } \\
\text { come assessment }\end{array}$ & $\begin{array}{l}\text { Incomplete out- } \\
\text { come data }\end{array}$ & $\begin{array}{l}\text { Selective re- } \\
\text { porting }\end{array}$ & $\begin{array}{l}\text { Overall judg- } \\
\text { ment }\end{array}$ \\
\hline Alon, 2008 [145] & Unclear & Unclear & Unclear & Unclear & Unclear & Low risk & Unclear \\
\hline $\begin{array}{l}\text { da Silva } \\
\text { Cameira o, } 2011 \\
{[141]}\end{array}$ & Unclear & Unclear & Unclear & Low risk & High risk & Low risk & High risk \\
\hline Lannin, 2016 [143] & Low risk & Low risk & High risk & Low risk & Low risk & High risk & Low risk \\
\hline $\begin{array}{l}\text { Nijenhuis, } 2017 \\
\text { [142] }\end{array}$ & Low risk & Unclear & High risk & High risk & Low risk & Low risk & High risk \\
\hline $\begin{array}{l}\text { Vilafane, } 2018 \\
\text { [147] }\end{array}$ & Low risk & Unclear & Low risk & Low risk & Low risk & Low risk & Unclear \\
\hline Wolf, 2015 [144] & Low risk & Unclear & High risk & Low risk & Low risk & Low risk & Unclear \\
\hline $\begin{array}{l}\text { Nakipoglu Yuzer, } \\
2017 \text { [146] }\end{array}$ & Low risk & Unclear & Unclear & Unclear & Low risk & Low risk & Unclear \\
\hline
\end{tabular}


Table 2. Downs and Black quality assessment summary.

\begin{tabular}{|c|c|c|c|c|}
\hline & \multicolumn{4}{|l|}{ Author, year } \\
\hline & Barry, 2012 [150] & Friedman, 2014 [148] & Knutson, 2016 [151] & Prange-Lasonder 2017 [149] \\
\hline \multicolumn{5}{|c|}{ Reporting } \\
\hline $1^{\mathrm{a}}$ & 1 & 1 & 1 & 1 \\
\hline $2^{\mathrm{b}}$ & 1 & 1 & 1 & 1 \\
\hline $3^{\mathrm{c}}$ & 1 & 1 & 1 & 1 \\
\hline $4^{\mathrm{d}}$ & 1 & 1 & 1 & 1 \\
\hline $5^{\mathrm{e}}$ & 2 & 2 & 2 & 2 \\
\hline $6^{\mathrm{f}}$ & 1 & 1 & 1 & 1 \\
\hline $7^{\mathrm{g}}$ & 1 & 1 & 1 & 0 \\
\hline $8^{\mathrm{h}}$ & 0 & 0 & 1 & 0 \\
\hline $9^{\mathrm{i}}$ & 1 & 0 & 1 & 0 \\
\hline $10^{\mathrm{j}}$ & 1 & 1 & 1 & 1 \\
\hline \multicolumn{5}{|c|}{ External validity } \\
\hline $11^{\mathrm{k}}$ & 0 & 1 & 0 & 0 \\
\hline $12^{1}$ & 0 & 1 & 0 & 0 \\
\hline $13^{\mathrm{m}}$ & $0 \mathrm{UTD}^{\mathrm{n}}$ & 0 UTD & 0 UTD & 0 UTD \\
\hline \multicolumn{5}{|c|}{ Internal validity-bias } \\
\hline $14^{\mathrm{o}}$ & 0 & 1 & 0 & 0 \\
\hline $15^{\mathrm{p}}$ & 1 & 1 & 1 & 0 \\
\hline $16^{\mathrm{q}}$ & 1 & 1 & 1 & 1 \\
\hline $17^{\mathrm{r}}$ & $0 \mathrm{~N} / \mathrm{A}^{\mathrm{s}}$ & 1 & 1 & 1 \\
\hline $18^{\mathrm{t}}$ & 1 & 1 & 1 & 1 \\
\hline $19^{\mathrm{u}}$ & $0 \mathrm{UTD}$ & 1 & 1 & 0 UTD \\
\hline $20^{\mathrm{v}}$ & 1 & 1 & 1 & 1 \\
\hline \multicolumn{5}{|c|}{ Internal validity—confounding (section bias) } \\
\hline $21^{\mathrm{w}}$ & $0 \mathrm{UTD}$ & 1 & 1 & 1 \\
\hline $22^{\mathrm{x}}$ & $0 \mathrm{UTD}$ & 0 UTD & $0 \mathrm{UTD}$ & $0 \mathrm{UTD}$ \\
\hline $23^{y}$ & 1 & 1 & 1 & 1 \\
\hline $24^{\mathrm{Z}}$ & 0 UTD & 1 & 0 UTD & 0 UTD \\
\hline $25^{\mathrm{aa}}$ & 0 UTD & 0 UTD & 0 UTD & 0 UTD \\
\hline $26^{\mathrm{ab}}$ & 1 & 0 UTD & 1 & 0 UTD \\
\hline \multicolumn{5}{|l|}{ Power } \\
\hline $27^{\mathrm{ac}}$ & 0 & 0 & 0 & 0 \\
\hline Total & 16 & 21 & 20 & 14 \\
\hline
\end{tabular}

${ }^{a}$ 1: Clarity of aims, objectives, and hypothesis.

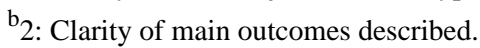

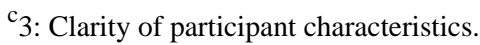




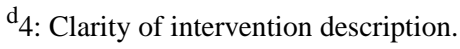

$\mathrm{e}_{5}$ : Clarity of distributions of principal confounders in each group.

${ }^{\mathrm{f}} 6$ : Are the main findings of the study clearly described?

$\mathrm{g}_{7}$ : Are estimates of random variability in data for main outcomes clearly described?

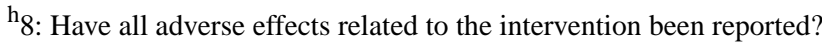

${ }^{\mathrm{i}} 9$ : Have lost to follow-up participant characteristics been described?

$\mathrm{j}_{10}$ : Have probability values for main outcomes been reported except from where $P<.001$ ?

$\mathrm{k}_{11}$ : Were the participants asked to take part in the study representative of the entire population from which they were recruited?

${ }_{12}^{1}$ : Were the participants prepared to take part in the study representative of the population from which they were recruited?

$\mathrm{m}_{13}$ : Were the staff, places, and facilities where the participants were treated representative of the treatment that the majority of patients receive?

${ }^{\mathrm{n}} \mathrm{UTD}$ : unable to determine.

${ }^{\mathrm{o}} 14$ : Was there an attempt to blind participants?

$\mathrm{p}_{15}$ : Was there an attempt to blind those measuring the main outcomes of the intervention?

${ }^{\mathrm{q}} 16$ : If any study results were based on data dredging, was this made clear?

${ }^{r} 17$ : In trials and cohort studies, do the analysis adjust for different lengths of follow-up of participants, or in case-control studies, is the time period between the intervention and outcome the same for cases and controls?

${ }^{\mathrm{s}}$ Not applicable.

${ }^{t} 18$ : Were the statistical tests used to assess the main outcomes appropriate?

$\mathrm{u}_{19}$ : Was intervention compliance reliable?

${ }^{2} 20$ : Were the main outcome measures used accurate (valid and reliable)?

${ }^{w_{2}} 2$ : Were the participants in different intervention groups (trials and cohort studies) or were the cases and controls (case-control studies) recruited from the same population?

$\mathrm{x}_{22}$ : Were the participants in different intervention groups (trials and cohort studies) or were the cases and controls (case-control studies) recruited over the same period of time?

$\mathrm{y}_{23}$ : Were participants randomized to the intervention groups?

$\mathrm{z}_{24}$ : Was the randomized intervention assignment concealed from both participants and health care staff until recruitment was complete and irrevocable?

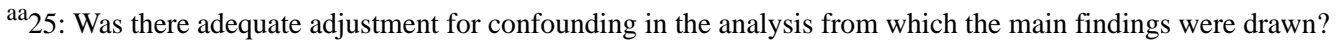

$\mathrm{ab}_{26}$ : Were losses to follow-up taken into account?

${ }^{\mathrm{ac}} 27$ : Did the study have sufficient power to detect a clinically important effect?

\section{Quality Assessment of Measurement Scales}

All of the outcome measures used in the 11 studies had the psychometric properties of the scale assessed previously with only the floor and ceiling effect of the BBT, JTHFT, the CAHAI, QuickDASH, and the UEFT not studied. The MAL had no evidence of content validity or predictive validity. The WMFT had no evidence of predictive and content validity or responsiveness.

From a clinimetric perspective, all of the scales with the exception of the UL item of the MAS, UEFT, and the JTHFT had defined MCID in the literature. All data, parametric or nonparametric, were analyzed using appropriate statistical methods. This quality assessment of outcome measurements used provides some confidence in the evidence reported by each study (see Multimedia Appendix 3 for further details of the outcome measures of quality assessment and Multimedia Appendix 6 for a summary of the included studies in this review).

The 11 included studies in this review had small sample sizes ranging from 5 to 99 participants at an average (mean) age of 57 years.

\section{Discussion}

\section{Principal Findings}

This review set out to answer the question What is the effectiveness of UL wearable technology for improving activity and participation in adult stroke survivors?

Following exclusions, outcome measure assessment and quality assessment, 11 studies were included (see Multimedia Appendix 6). Of the 11 studies included, only one [141] found significant between-group differences using the CAHAI. However, this study was assessed as being high risk (see Table 1 and Multimedia Appendix 4) because of having $>20 \%$ dropout rate. This study also included acute stroke survivors <19 days poststroke, which could mean that improvements are subject to acute natural improvement such as the spontaneous recovery following stroke [152]. Some improvements were found across all the studies included for both the control and intervention groups who all had an increase in rehabilitation dosage. This may suggest that a key mechanism for improvement is increasing the amount of rehabilitation carried out, which has been recognized in the national clinical guidelines for stroke [5]. However, further research is required to distinguish between the mechanism of dosage and intensity where dosage is the amount of rehabilitation activity and intensity is the amount of rehabilitation over time [153]. In other words, is it more effective to carry out more rehabilitation or is more effective to carry out more rehabilitation in a shorter period of time? 
The 11 studies included in this review had small sample sizes ranging from 5 to 99 participants at an average (mean) age of 57 years old, whereas in England, Wales, and Northern Ireland, the average age for men to have a stroke is 74 and the average age for women to have a stroke is 80 [154]. It is also important to note that only one of the RCTs [143] was assessed as being low risk using the CRoB tool and of the non-RCTs [148-151], all obtained low scores on the Downs and Black instrument (14-21 out of 32), particularly for the external validity and selection bias domains. This suggests that the results may be difficult to generalize to the wider stroke population. However, quality appraisal is reliant on adequate reporting and some interventions may rely heavily on direct clinical input, which negates the ability to blind the participants and assessors.

A total of 12 outcome measures were used across the studies (11 functionals and 1 participation) to assess the effectiveness of the intervention in their respective ICF domains. A review of each of the outcome measures used to determine if the psychometric properties, the clinimetric properties, and the method of analysis were suitable revealed that all data had been analyzed appropriately. However, the UL item of the MAS, UEFT, and the JTHFT are yet to establish the MCID. This is important as it represents the smallest improvement considered worthwhile by a patient. The concept of an MCID is offered as the new standard for determining effectiveness of a given treatment and describing patient satisfaction in reference to that treatment [155]. Although some studies may reveal statistical significance, this may not mean that the intervention has made a meaningful difference to the functional capability of the stroke survivor.

An RCT methodology aims to control the conditions of each arm of a study to reduce bias [156]. Using technology to facilitate independent poststroke rehabilitation involves combining complex interventions with a complex condition. No two strokes are the same and no two contexts of adoption are the same. There are many complex nuances involved in using a device, independently often in the home environment. Therefore, using methodologies that account for these differences are important such as realist evaluation [157,158].

The use of technology to facilitate independent poststroke rehabilitation has the potential to motivate stroke survivors in that they are often interactive, fun to use, and engaging [12]. Furthermore, technologies have the potential to measure intervention outcomes over long periods of time that would normally be undetectable (ie, muscle activity in microvolts); provide formative, summative, and real-time feedback to the user in ways that could not be provided by a therapist (ie, the use of readily available graphics); and provide guidance and instruction out of clinical sessions. However, the lack of large, robust clinical trials can limit the uptake and acceptance of technological interventions in clinical practice. Indeed, since Moore's law published in 1965, which observed that the number of transistors on integrated circuits doubles approximately every 2 years [159], one of the difficulties is keeping up with the speed of new technologies against the time it takes to provide high-level clinical evidence. However, the recent publication of the National Institute for Health and Care Excellence Evidence Standards Framework for Digital Health Technologies (DHTs) sets out to describe standards for the evidence that should be available, or developed, for DHTs to demonstrate their value in the UK health and care system could speed up the uptake of DHTs [160].

The results of the included studies were not combined for a meta-analysis due to the varied types of data collected for the primary outcome measures. It would also be difficult to compare primary outcomes across the included studies accurately as there were a wide variety of functional and participation outcome measures used across the studies.

Future research could focus on adopting the principles and concept of technology use rather than on a specific device. Nonetheless, conventional research rigor is still required including robust methodologies that account for the complexity of use, larger sample sizes that reflect the population, valid, reliable measurement tools with MCID values, and importantly, the technology is suitable for the purpose of use.

\section{Conclusions}

This review found that there is little evidence in the literature to support the use of wearable technologies to improve activity and participation for independent UL rehabilitation following a stroke. However, this may be because of small sample sizes and the limitations of using an RCT and randomized comparison trial methodology with a complex intervention and with a complex condition. The studies included in this review did highlight that improvements can be made when more rehabilitation is carried out, but the mechanisms of this are yet to be investigated fully. Future technologies may have the potential to measure outcomes, provide feedback, and engage users outside of clinical sessions. This could provide a platform for motivating stroke survivors to carry out more rehabilitation in the absence of a therapist, which could maximize recovery.

\section{Acknowledgments}

This research was funded and supported by the National Institute for Health Research (NIHR) Collaboration for Leadership in Applied Health Research and Care Yorkshire and Humber. The views and opinions expressed are those of the authors and are not necessarily those of the National Health Service, the NIHR, or the Department of Health, United Kingdom.

\section{Conflicts of Interest}

None declared. 


\section{Multimedia Appendix 1}

Medline search strategy.

[DOCX File, 17 KB-Multimedia Appendix 1]

\section{Multimedia Appendix 2}

Full text papers and reasons for exclusions.

[DOCX File, 65 KB-Multimedia Appendix 2]

\section{Multimedia Appendix 3}

Details of outcome measure quality assessment.

[DOCX File, 14 KB-Multimedia Appendix 3]

\section{Multimedia Appendix 4}

Details of quality assessment for included RCTs.

[DOCX File, 15 KB-Multimedia Appendix 4]

\section{Multimedia Appendix 5}

Details of quality assessment for non-RCT study designs.

[DOCX File, 15 KB-Multimedia Appendix 5]

\section{Multimedia Appendix 6}

Summary of included studies in this review.

[DOCX File, 107 KB-Multimedia Appendix 6]

\section{References}

1. GBD 2016 Stroke Collaborators. Global, regional, and national burden of stroke, 1990-2016: a systematic analysis for the Global Burden of Disease Study 2016. Lancet Neurol 2019 May;18(5):439-458 [FREE Full text] [doi:

10.1016/S1474-4422(19)30034-1] [Medline: 30871944]

2. Xu X, Vestesson E, Paley L, Desikan A, Wonderling D, Hoffman A, et al. The economic burden of stroke care in England, Wales and Northern Ireland: Using a national stroke register to estimate and report patient-level health economic outcomes in stroke. Eur Stroke J 2018 Mar;3(1):82-91 [FREE Full text] [doi: 10.1177/2396987317746516] [Medline: 29900412]

3. Kwah LK, Harvey LA, Diong J, Herbert RD. Models containing age and NIHSS predict recovery of ambulation and upper limb function six months after stroke: an observational study. J Physiother 2013 Sep;59(3):189-197 [FREE Full text] [doi: 10.1016/S1836-9553(13)70183-8] [Medline: 23896334]

4. Morris JH, van Wijck F, Joice S, Donaghy M. Predicting health related quality of life 6 months after stroke: the role of anxiety and upper limb dysfunction. Disabil Rehabil 2013 Feb;35(4):291-299. [doi: 10.3109/09638288.2012.691942] [Medline: 22691224]

5. Inercollegiate Stroke Working Party. National Clinical Guideline for Stroke. London: Royal College of Physicians; 2016.

6. Fryer CE, Luker JA, McDonnell MN, Hillier SL. Self management programmes for quality of life in people with stroke. Cochrane Database Syst Rev 2016 Aug 22(8):CD010442 [FREE Full text] [doi: 10.1002/14651858.CD010442.pub2] [Medline: 27545611]

7. Powell L, Parker J, Martyn St-James M, Mawson S. The effectiveness of lower-limb wearable technology for improving activity and participation in adult stroke survivors: a systematic review. J Med Internet Res 2016 Oct 7;18(10):e259 [FREE Full text] [doi: 10.2196/jmir.5891] [Medline: 27717920]

8. Wang Q, Markopoulos P, Yu B, Chen W, Timmermans A. Interactive wearable systems for upper body rehabilitation: a systematic review. J Neuroeng Rehabil 2017 Mar 11;14(1):20 [FREE Full text] [doi: 10.1186/s12984-017-0229-y] [Medline: 28284228]

9. Parker J, Mountain G, Hammerton J. A review of the evidence underpinning the use of visual and auditory feedback for computer technology in post-stroke upper-limb rehabilitation. Disabil Rehabil Assist Technol 2011;6(6):465-472. [doi: 10.3109/17483107.2011.556209] [Medline: 21314295]

10. Burridge JH, Lee AC, Turk R, Stokes M, Whitall J, Vaidyanathan R, et al. Telehealth, wearable sensors, and the internet: will they improve stroke outcomes through increased intensity of therapy, motivation, and adherence to rehabilitation programs? J Neurol Phys Ther 2017 Jul;41(Suppl 3):S32-S38. [doi: 10.1097/NPT.0000000000000183] [Medline: 28628594] 
11. Morone G, Giardi S, Gooshchy S, Iosa M, Paolucci S. Wearable Devices and Virtual Reality for Neurorehabilitation: An Opportunity for Home Rehabilitation. In: Proceedings of the 2018 International Conference on NeuroRehabilitation. 2018 Presented at: ICNR'18; October 16-20, 2018; Pisa, Italy. [doi: 10.1007/978-3-030-01845-0 120]

12. Rodgers MM, Alon G, Pai VM, Conroy RS. Wearable technologies for active living and rehabilitation: current research challenges and future opportunities. J Rehabil Assist Technol Eng 2019;6:2055668319839607 [FREE Full text] [doi: 10.1177/2055668319839607] [Medline: 31245033 ]

13. Dobkin BH, Martinez C. Wearable sensors to monitor, enable feedback, and measure outcomes of activity and practice. Curr Neurol Neurosci Rep 2018 Oct 6;18(12):87. [doi: 10.1007/s11910-018-0896-5] [Medline: 30293160]

14. Gebruers N, Vanroy C, Truijen S, Engelborghs S, de Deyn PP. Monitoring of physical activity after stroke: a systematic review of accelerometry-based measures. Arch Phys Med Rehabil 2010 Feb;91(2):288-297. [doi: 10.1016/j.apmr.2009.10.025] [Medline: 20159136]

15. Patel S, Park H, Bonato P, Chan L, Rodgers M. A review of wearable sensors and systems with application in rehabilitation. J Neuroeng Rehabil 2012 Apr 20;9:21 [FREE Full text] [doi: 10.1186/1743-0003-9-21] [Medline: 22520559]

16. Steins D, Dawes H, Esser P, Collett J. Wearable accelerometry-based technology capable of assessing functional activities in neurological populations in community settings: a systematic review. J Neuroeng Rehabil 2014 Mar 13;11:36 [FREE Full text] [doi: 10.1186/1743-0003-11-36] [Medline: 24625308]

17. Zheng H, Black ND, Harris ND. Position-sensing technologies for movement analysis in stroke rehabilitation. Med Biol Eng Comput 2005 Jul;43(4):413-420. [doi: 10.1007/bf02344720] [Medline: 16255421]

18. Wang Q, Timmermans A, Chen W, Jia J, Ding L, Xiong L, et al. Stroke patients' acceptance of a smart garment for supporting upper extremity rehabilitation. IEEE J Transl Eng Health Med 2018;6:2101009 [FREE Full text] [doi: 10.1109/JTEHM.2018.2853549] [Medline: 30519515]

19. Davies RJ, Parker J, McCullagh P, Zheng H, Nugent C, Black ND, et al. A personalized self-management rehabilitation system for stroke survivors: a quantitative gait analysis using a smart insole. JMIR Rehabil Assist Technol 2016 Nov 8;3(2):e11 [FREE Full text] [doi: 10.2196/rehab.5449] [Medline: 28582260]

20. Mawson S, Nasr N, Parker J, Davies R, Zheng H, Mountain G. A personalized self-management rehabilitation system with an intelligent shoe for stroke survivors: a realist evaluation. JMIR Rehabil Assist Technol 2016 Jan 7;3(1):e1 [FREE Full text] [doi: 10.2196/rehab.5079] [Medline: 28582250]

21. Munoz-Organero M, Parker J, Powell L, Davies R, Mawson S. Sensor optimization in smart insoles for post-stroke gait asymmetries using total variation and L 1 distances. IEEE Sensors J 2017;17(10):3142-3151. [doi: 10.1109/jsen.2017.2686641]

22. Munoz-Organero M, Parker J, Powell L, Mawson S. Assessing walking strategies using insole pressure sensors for stroke survivors. Sensors (Basel) 2016 Oct 1;16(10):pii: E1631 [FREE Full text] [doi: 10.3390/s16101631] [Medline: 27706077]

23. Asada H, Shaltis P, Reisner A, Rhee S, Hutchinson R. Mobile monitoring with wearable photoplethysmographic biosensors. IEEE Eng Med Biol Mag 2003;22(3):28-40. [doi: 10.1109/memb.2003.1213624] [Medline: 12845817]

24. Shaltis PA, Reisner A, Asada HH. Wearable, cuff-less PPG-based blood pressure monitor with novel height sensor. Conf Proc IEEE Eng Med Biol Soc 2006;1:908-911. [doi: 10.1109/IEMBS.2006.260027] [Medline: 17946006]

25. Veerbeek JM, Langbroek-Amersfoort AC, van Wegen EE, Meskers CG, Kwakkel G. Effects of robot-assisted therapy for the upper limb after stroke. Neurorehabil Neural Repair 2017 Feb;31(2):107-121. [doi: 10.1177/1545968316666957] [Medline: 27597165]

26. Laver KE, Lange B, George S, Deutsch JE, Saposnik G, Crotty M. Virtual reality for stroke rehabilitation. Cochrane Database Syst Rev 2017 Nov 20;11:CD008349 [FREE Full text] [doi: 10.1002/14651858.CD008349.pub4] [Medline: 29156493]

27. Eraifej J, Clark W, France B, Desando S, Moore D. Effectiveness of upper limb functional electrical stimulation after stroke for the improvement of activities of daily living and motor function: a systematic review and meta-analysis. Syst Rev 2017 Feb 28;6(1):40 [FREE Full text] [doi: 10.1186/s13643-017-0435-5] [Medline: 28245858]

28. Howlett OA, Lannin NA, Ada L, McKinstry C. Functional electrical stimulation improves activity after stroke: a systematic review with meta-analysis. Arch Phys Med Rehabil 2015 May;96(5):934-943. [doi: 10.1016/j.apmr.2015.01.013] [Medline: 25634620]

29. Teasell RW, Bhogal SK, Foley NC, Speechley MR. Gait retraining post stroke. Top Stroke Rehabil 2003;10(2):34-65. [doi: 10.1310/UDXE-MJFF-53V2-EAP0] [Medline: 13680517]

30. Mahmood A, Veluswamy SK, Hombali A, Mullick A, Solomon JM. Effect of transcutaneous electrical nerve stimulation on spasticity in adults with stroke: a systematic review and meta-analysis. Arch Phys Med Rehabil 2019 Apr;100(4):751-768. [doi: 10.1016/j.apmr.2018.10.016] [Medline: 30452892]

31. Marcolino MA, Hauck M, Stein C, Schardong J, Pagnussat AD, Plentz RD. Effects of transcutaneous electrical nerve stimulation alone or as additional therapy on chronic post-stroke spasticity: systematic review and meta-analysis of randomized controlled trials. Disabil Rehabil 2018 Oct 16:1-13. [doi: 10.1080/09638288.2018.1503736] [Medline: 30326752]

32. Mills PB, Dossa F. Transcutaneous electrical nerve stimulation for management of limb spasticity: a systematic review. Am J Phys Med Rehabil 2016 Apr;95(4):309-318. [doi: 10.1097/PHM.0000000000000437] [Medline: 26829077] 
33. Kleim JA, Jones TA. Principles of experience-dependent neural plasticity: implications for rehabilitation after brain damage. J Speech Lang Hear Res 2008 Feb;51(1):S225-S239. [doi: 10.1044/1092-4388(2008/018)] [Medline: 18230848]

34. World Health Organisation. World Health Organization. 2001. International Classification of Functioning, Disability and Health. URL: https://www.who.int/classifications/icf/en/ [accessed 2019-11-07]

35. Geyh S, Cieza A, Schouten J, Dickson H, Frommelt P, Omar Z, et al. ICF Core Sets for stroke. J Rehabil Med 2004 Jul(44 Suppl):135-141 [FREE Full text] [doi: 10.1080/16501960410016776] [Medline: 15370761]

36. Gottlieb A, Golander H, Bar-Tal Y, Gottlieb D. The influence of social support and perceived control on handicap and quality of life after stroke. Aging (Milano) 2001 Feb;13(1):11-15. [doi: 10.1007/bf03351488] [Medline: 11292146]

37. Moher D, Liberati A, Tetzlaff J, Altman DG, PRISMA Group. Preferred reporting items for systematic reviews and meta-analyses: the PRISMA statement. Ann Intern Med 2009 Aug 18;151(4):264-9, W64. [doi:

10.7326/0003-4819-151-4-200908180-00135] [Medline: 19622511]

38. Godfrey A, Hetherington V, Shum H, Bonato P, Lovell NH, Stuart S. From A to Z: Wearable technology explained. Maturitas 2018 Jul;113:40-47 [FREE Full text] [doi: 10.1016/j.maturitas.2018.04.012] [Medline: 29903647]

39. McKenzie JE, Brennan SE, Ryan RE, Thompson J, Johnston RV, Thomas J. Chapter 3: Defining the criteria for including studies and how they will be grouped for the synthesis. In: Higgins JP, Thomas J, Chandler J, Cumpston M, Li T, Page MJ, et al, editors. Cochrane Handbook for Systematic Reviews of Interventionsversion 6.0. London: Cochrane; 2019.

40. Salter K, Jutai JW, Teasell R, Foley NC, Bitensky J. Issues for selection of outcome measures in stroke rehabilitation: ICF Body Functions. Disabil Rehabil 2005 Feb 18;27(4):191-207. [doi: 10.1080/09638280400008537] [Medline: 15824050]

41. Platz T, Pinkowski C, van Wijck F, Kim I, di Bella P, Johnson G. Reliability and validity of arm function assessment with standardized guidelines for the Fugl-Meyer Test, Action Research Arm Test and Box and Block Test: a multicentre study. Clin Rehabil 2005 Jun;19(4):404-411. [doi: 10.1191/0269215505cr832oa] [Medline: 15929509]

42. Lyle RC. A performance test for assessment of upper limb function in physical rehabilitation treatment and research. Int $\mathbf{J}$ Rehabil Res 1981;4(4):483-492. [doi: 10.1097/00004356-198112000-00001] [Medline: 7333761]

43. Hsueh IP, Lee MM, Hsieh CL. Psychometric characteristics of the Barthel activities of daily living index in stroke patients. J Formos Med Assoc 2001 Aug;100(8):526-532. [Medline: 11678002]

44. Barreca S, Gowland CK, Stratford P, Huijbregts M, Griffiths J, Torresin W, et al. Development of the Chedoke arm and hand activity inventory: theoretical constructs, item generation, and selection. Top Stroke Rehabil 2004;11(4):31-42. [doi: 10.1310/JU8P-UVK6-68VW-CF3W] [Medline: 15592988]

45. Barreca SR, Stratford PW, Lambert CL, Masters LM, Streiner DL. Test-retest reliability, validity, and sensitivity of the Chedoke arm and hand activity inventory: a new measure of upper-limb function for survivors of stroke. Arch Phys Med Rehabil 2005 Aug;86(8):1616-1622. [doi: 10.1016/j.apmr.2005.03.017] [Medline: 16084816]

46. Barreca SR, Stratford PW, Masters LM, Lambert CL, Griffiths J. Comparing 2 versions of the Chedoke Arm and Hand Activity Inventory with the Action Research Arm Test. Phys Ther 2006 Feb;86(2):245-253. [Medline: 16445338]

47. Barreca SR, Stratford PW, Masters LM, Lambert CL, Griffiths J, McBay C. Validation of three shortened versions of the Chedoke arm and Hand Activity Inventory. Physiother Can 2006;58(02):148 [FREE Full text] [doi: 10.2310/6640.2006.00031]

48. Jebsen RH, Taylor N, Trieschmann RB, Trotter MJ, Howard LA. An objective and standardized test of hand function. Arch Phys Med Rehabil 1969;50(6):311-319. [Medline: 5788487]

49. Wolf SL, Catlin PA, Ellis M, Archer AL, Morgan B, Piacentino A. Assessing Wolf motor function test as outcome measure for research in patients after stroke. Stroke 2001 Jul;32(7):1635-1639. [doi: 10.1161/01.str.32.7.1635] [Medline: 11441212]

50. Uswatte G, Taub E, Morris D, Light K, Thompson PA. The Motor Activity Log-28: assessing daily use of the hemiparetic arm after stroke. Neurology 2006 Oct 10;67(7):1189-1194. [doi: 10.1212/01.wnl.0000238164.90657.c2] [Medline: 17030751]

51. Poole JL, Whitney SL. Motor assessment scale for stroke patients: concurrent validity and interrater reliability. Arch Phys Med Rehabil 1988 Mar;69(3 Pt 1):195-197. [Medline: 3348720]

52. Duncan PW, Bode RK, Min Lai S, Perera S, Glycine Antagonist in Neuroprotection Americans Investigators. Rasch analysis of a new stroke-specific outcome scale: the Stroke Impact Scale. Arch Phys Med Rehabil 2003 Jul;84(7):950-963. [doi: 10.1016/s0003-9993(03)00035-2] [Medline: 12881816]

53. Adams SA, Ashburn A, Pickering RM, Taylor D. The scalability of the Rivermead Motor Assessment in acute stroke patients. Clin Rehabil 1997 Feb;11(1):42-51. [doi: 10.1177/026921559701100107] [Medline: 9065359]

54. Carroll D. A quantitative test of upper extremity function. J Chronic Dis 1965 May;18:479-491. [doi: 10.1016/0021-9681(65)90030-5] [Medline: 14293031]

55. Beaton DE, Wright JG, Katz JN, Upper Extremity Collaborative Group. Development of the QuickDASH: comparison of three item-reduction approaches. J Bone Joint Surg Am 2005 May;87(5):1038-1046. [doi: 10.2106/JBJS.D.02060] [Medline: 15866967]

56. Gladstone DJ, Danells CJ, Black SE. The Fugl-Meyer assessment of motor recovery after stroke: a critical review of its measurement properties. Neurorehabil Neural Repair 2002 Sep;16(3):232-240. [doi: 10.1177/154596802401105171] [Medline: 12234086$]$

57. O'Dell MW, Kim G, Rivera L, Fieo R, Christos P, Polistena C, et al. A psychometric evaluation of the Arm Motor Ability Test. J Rehabil Med 2013 Jun;45(6):519-527 [FREE Full text] [doi: 10.2340/16501977-1138] [Medline: 23532275] 
58. Price DD, McGrath PA, Rafii A, Buckingham B. The validation of visual analogue scales as ratio scale measures for chronic and experimental pain. Pain 1983 Sep;17(1):45-56. [doi: 10.1016/0304-3959(83)90126-4] [Medline: 6226917]

59. Higgins JP, Altman DG. Assessing risk of bias in included studies. In: Higgins JP, Green S, editors. Cochrane Handbook for Systematic Reviews of Interventions. Hoboken, New Jersey: Wiley; 2008:187-241.

60. Tanaka N, Saitou H, Takao T, Iizuka N, Okuno J, Yano H, et al. Effects of gait rehabilitation with a footpad-type locomotion interface in patients with chronic post-stroke hemiparesis: a pilot study. Clin Rehabil 2012 Aug;26(8):686-695. [doi: 10.1177/0269215511432356] [Medline: 22275464]

61. Downs SH, Black N. The feasibility of creating a checklist for the assessment of the methodological quality both of randomised and non-randomised studies of health care interventions. J Epidemiol Community Health 1998 Jun;52(6):377-384 [FREE Full text] [doi: 10.1136/jech.52.6.377] [Medline: 9764259]

62. Tyson S, Connell L. The psychometric properties and clinical utility of measures of walking and mobility in neurological conditions: a systematic review. Clin Rehabil 2009 Nov;23(11):1018-1033. [doi: 10.1177/0269215509339004] [Medline: 19786420]

63. Altaim T. White Rose eTheses Online. 2015. Developing a Functional Outcome Measure for Individuals With Low Back Pain Within a Jordanian Physiotherapy Service. URL: http://etheses.whiterose.ac.uk/9602/1/

Thesis_Thamer\%20Altaim_Draft_8August2015_Final.pdf [accessed 2019-11-07]

64. de Vet HC, Terwee CB, Bouter LM. Current challenges in clinimetrics. J Clin Epidemiol 2003 Dec;56(12):1137-1141. [doi: 10.1016/j.jclinepi.2003.08.012] [Medline: 14680660]

65. Feinstein AR. An additional basic science for clinical medicine: IV. The development of clinimetrics. Ann Intern Med 1983 Dec;99(6):843-848. [doi: 10.7326/0003-4819-99-6-843] [Medline: $\underline{6651026}$ ]

66. Kirshner B, Guyatt G. A methodological framework for assessing health indices. J Chronic Dis 1985;38(1):27-36. [doi: 10.1016/0021-9681(85)90005-0] [Medline: 3972947]

67. Okasheh RO. Sheffield Hallam University Research Archive. 2011. Clinical Measurement of Functional Outcomes of Pulmonary Rehabilitation. URL: http://shura.shu.ac.uk/20771/1/10702873.pdf [accessed 2019-11-07]

68. Mawson SJ. Measuring physiotherapy outcome in stroke rehabilitation. Physiother 1993;79(11):762-765. [doi: 10.1016/s0031-9406(10)60057-0]

69. Michels E. Measurement in physical therapy. On the rules for assigning numerals to observations. Phys Ther 1983 Feb;63(2):209-215. [doi: 10.1093/ptj/63.2.209] [Medline: 6823471]

70. Stevens SS. On the theory of scales of measurement. Science 1946 Jun 7;103(2684):677-680. [doi: 10.1126/science.103.2684.677] [Medline: 17750512]

71. Weiss PL, Rand D, Katz N, Kizony R. Video capture virtual reality as a flexible and effective rehabilitation tool. J Neuroeng Rehabil 2004 Dec 20;1(1):12 [FREE Full text] [doi: 10.1186/1743-0003-1-12] [Medline: 15679949]

72. Nelson AM. Addressing the threat of evidence-based practice to qualitative inquiry through increasing attention to quality: a discussion paper. Int J Nurs Stud 2008 Feb;45(2):316-322. [doi: 10.1016/j.ijnurstu.2007.01.012] [Medline: 17362956]

73. Mullen EJ, Streiner DL. The evidence for and against evidence-based practice. In: Roberts AR, Yeager K, editors. Foundations of Evidence-Based Social Work Practice. Oxford, UK: Oxford University Press; 2006:21-34.

74. Ang KK, Guan C, Phua KS, Wang C, Zhao L, Teo WP, et al. Facilitating effects of transcranial direct current stimulation on motor imagery brain-computer interface with robotic feedback for stroke rehabilitation. Arch Phys Med Rehabil 2015 Mar;96(3 Suppl):S79-S87. [doi: 10.1016/j.apmr.2014.08.008] [Medline: 25721551]

75. Bach P, Knoblich G, Gunter TC, Friederici AD, Prinz W. Action comprehension: deriving spatial and functional relations. J Exp Psychol Hum Percept Perform 2005 Jun;31(3):465-479. [doi: 10.1037/0096-1523.31.3.465] [Medline: 15982126]

76. Cameirão MS, Badia SB, Duarte E, Frisoli A, Verschure PF. The combined impact of virtual reality neurorehabilitation and its interfaces on upper extremity functional recovery in patients with chronic stroke. Stroke 2012 Oct;43(10):2720-2728. [doi: 10.1161/STROKEAHA.112.653196] [Medline: 22871683]

77. Carey JR, Kimberley TJ, Lewis SM, Auerbach EJ, Dorsey L, Rundquist P, et al. Analysis of fMRI and finger tracking training in subjects with chronic stroke. Brain 2002 Apr;125(Pt 4):773-788. [doi: 10.1093/brain/awf091] [Medline: 11912111]

78. Germanotta M, Cruciani A, Pecchioli C, Loreti S, Spedicato A, Meotti M, et al. Reliability, validity and discriminant ability of the instrumental indices provided by a novel planar robotic device for upper limb rehabilitation. J Neuroeng Rehabil 2018 May 16;15(1):39 [FREE Full text] [doi: 10.1186/s12984-018-0385-8] [Medline: 29769127]

79. Hayward KS, Barker RN, Brauer SG, Lloyd D, Horsley SA, Carson RG. SMART Arm with outcome-triggered electrical stimulation: a pilot randomized clinical trial. Top Stroke Rehabil 2013;20(4):289-298. [doi: 10.1310/tsr2004-289] [Medline: 23893828]

80. Hussain I, Salvietti G, Spagnoletti G, Malvezzi M, Cioncoloni D, Rossi S, et al. A soft supernumerary robotic finger and mobile arm support for grasping compensation and hemiparetic upper limb rehabilitation. Robot Auton Syst 2017;93:1-12 [FREE Full text] [doi: 10.1016/j.robot.2017.03.015]

81. Kairy D, Veras M, Archambault P, Hernandez A, Higgins J, Levin MF, et al. Maximizing post-stroke upper limb rehabilitation using a novel telerehabilitation interactive virtual reality system in the patient's home: study protocol of a randomized clinical trial. Contemp Clin Trials 2016 Mar;47:49-53. [doi: 10.1016/j.cct.2015.12.006] [Medline: 26655433] 
82. Kim T, Kim S, Lee B. Effects of action observational training plus brain-computer interface-based functional electrical stimulation on paretic arm motor recovery in patient with stroke: a randomized controlled trial. Occup Ther Int 2016 Mar;23(1):39-47. [doi: 10.1002/oti.1403] [Medline: 26301519]

83. Kim GJ, Hinojosa J, Rao AK, Batavia M, O'Dell MW. Randomized trial on the effects of attentional focus on motor training of the upper extremity using robotics with individuals after chronic stroke. Arch Phys Med Rehabil 2017 Oct;98(10):1924-1931. [doi: 10.1016/j.apmr.2017.06.005] [Medline: 28652064]

84. Kimberley TJ, Lewis SM, Auerbach EJ, Dorsey LL, Lojovich JM, Carey JR. Electrical stimulation driving functional improvements and cortical changes in subjects with stroke. Exp Brain Res 2004 Feb;154(4):450-460. [doi: 10.1007/s00221-003-1695-y] [Medline: 14618287]

85. Kiper P, Agostini M, Luque-Moreno C, Tonin P, Turolla A. Reinforced feedback in virtual environment for rehabilitation of upper extremity dysfunction after stroke: preliminary data from a randomized controlled trial. Biomed Res Int 2014;2014:752128 [FREE Full text] [doi: 10.1155/2014/752128] [Medline: 24745024]

86. Klamroth-Marganska V, Blanco J, Campen K, Curt A, Dietz V, Ettlin T, et al. Three-dimensional, task-specific robot therapy of the arm after stroke: a multicentre, parallel-group randomised trial. Lancet Neurol 2014 Feb;13(2):159-166. [doi: 10.1016/S1474-4422(13)70305-3] [Medline: 24382580]

87. Lee JM, Jung J, Park KW, Shin E, Oh SK, Bae J, et al. Harmonizing Optimal Strategy for Treatment of coronary artery diseases--comparison of REDUCtion of prasugrEl dose or POLYmer TECHnology in ACS patients

(HOST-REDUCE-POLYTECH-ACS RCT): study protocol for a randomized controlled trial. Trials 2015 Sep 15;16:409 [FREE Full text] [doi: 10.1186/s13063-015-0925-5] [Medline: 26374625]

88. Lemmens RJ, Timmermans AA, Janssen-Potten YJ, Pulles SA, Geers RP, Bakx WG, et al. Accelerometry measuring the outcome of robot-supported upper limb training in chronic stroke: a randomized controlled trial. PLoS One 2014;9(5):e96414 [FREE Full text] [doi: 10.1371/journal.pone.0096414] [Medline: 24823925]

89. Leonardis D, Barsotti M, Loconsole C, Solazzi M, Troncossi M, Mazzotti C, et al. An EMG-controlled robotic hand exoskeleton for bilateral rehabilitation. IEEE Trans Haptics 2015;8(2):140-151. [doi: 10.1109/TOH.2015.2417570] [Medline: 25838528]

90. Li H, Huang G, Lin Q, Zhao J, Lo WA, Mao Y, et al. Combining movement-related cortical potentials and event-related desynchronization to study movement preparation and execution. Front Neurol 2018;9:822 [FREE Full text] [doi: 10.3389/fneur.2018.00822] [Medline: 30344504]

91. Linder SM, Rosenfeldt AB, Reiss A, Buchanan S, Sahu K, Bay CR, et al. The home stroke rehabilitation and monitoring system trial: a randomized controlled trial. Int J Stroke 2013 Jan;8(1):46-53 [FREE Full text] [doi: 10.1111/j.1747-4949.2012.00971.x] [Medline: 23280269]

92. Lo AC, Guarino PD, Richards LG, Haselkorn JK, Wittenberg GF, Federman DG, et al. Robot-assisted therapy for long-term upper-limb impairment after stroke. N Engl J Med 2010 May 13;362(19):1772-1783 [FREE Full text] [doi:

10.1056/NEJMoa0911341] [Medline: 20400552]

93. Lum PS, Burgar CG, Shor PC, Majmundar M, Van der Loos M. Robot-assisted movement training compared with conventional therapy techniques for the rehabilitation of upper-limb motor function after stroke. Arch Phys Med Rehabil 2002 Jul;83(7):952-959. [doi: 10.1053/apmr.2001.33101] [Medline: 12098155]

94. Lum PS, Burgar CG, Van der Loos M, Shor PC, Majmundar M, Yap R. MIME robotic device for upper-limb neurorehabilitation in subacute stroke subjects: a follow-up study. J Rehabil Res Dev 2006;43(5):631-642 [FREE Full text] [doi: 10.1682/jrrd.2005.02.0044] [Medline: 17123204]

95. Masiero S, Celia A, Armani M, Rosati G. A novel robot device in rehabilitation of post-stroke hemiplegic upper limbs. Aging Clin Exp Res 2006 Dec;18(6):531-535. [Medline: 17255643]

96. Masiero S, Celia A, Rosati G, Armani M. Robotic-assisted rehabilitation of the upper limb after acute stroke. Arch Phys Med Rehabil 2007 Feb;88(2):142-149. [doi: 10.1016/j.apmr.2006.10.032] [Medline: 17270510]

97. Masiero S, Armani M, Rosati G. Upper-limb robot-assisted therapy in rehabilitation of acute stroke patients: focused review and results of new randomized controlled trial. J Rehabil Res Dev 2011;48(4):355-366 [FREE Full text] [doi: 10.1682/jrrd.2010.04.0063] [Medline: 21674388]

98. Masiero S, Armani M, Ferlini G, Rosati G, Rossi A. Randomized trial of a robotic assistive device for the upper extremity during early inpatient stroke rehabilitation. Neurorehabil Neural Repair 2014 May;28(4):377-386. [doi: 10.1177/1545968313513073] [Medline: 24316679]

99. McCabe J, Monkiewicz M, Holcomb J, Pundik S, Daly JJ. Comparison of robotics, functional electrical stimulation, and motor learning methods for treatment of persistent upper extremity dysfunction after stroke: a randomized controlled trial. Arch Phys Med Rehabil 2015 Jun;96(6):981-990 [FREE Full text] [doi: 10.1016/j.apmr.2014.10.022] [Medline: 25461822]

100. McNulty PA, Thompson-Butel AG, Faux SG, Lin G, Katrak PH, Harris LR, et al. The efficacy of Wii-based Movement Therapy for upper limb rehabilitation in the chronic poststroke period: a randomized controlled trial. Int J Stroke 2015 Dec;10(8):1253-1260. [doi: 10.1111/ijs.12594] [Medline: 26332338]

101. Metzger J, Lambercy O, Califfi A, Dinacci D, Petrillo C, Rossi P, et al. Assessment-driven selection and adaptation of exercise difficulty in robot-assisted therapy: a pilot study with a hand rehabilitation robot. J Neuroeng Rehabil 2014 Nov 15;11:154 [FREE Full text] [doi: 10.1186/1743-0003-11-154] [Medline: 25399249] 
102. Orihuela-Espina F, Roldán GF, Sánchez-Villavicencio I, Palafox L, Leder R, Sucar LE, et al. Robot training for hand motor recovery in subacute stroke patients: a randomized controlled trial. J Hand Ther 2016;29(1):51-7; quiz 57. [doi: 10.1016/j.jht.2015.11.006] [Medline: 26847320 ]

103. Prange GB, Kottink AI, Buurke JH, Eckhardt MM, van Keulen-Rouweler BJ, Ribbers GM, et al. The effect of arm support combined with rehabilitation games on upper-extremity function in subacute stroke: a randomized controlled trial. Neurorehabil Neural Repair 2015 Feb;29(2):174-182. [doi: 10.1177/1545968314535985] [Medline: 24878589]

104. Piron L, Turolla A, Agostini M, Zucconi C, Cortese F, Zampolini M, et al. Exercises for paretic upper limb after stroke: a combined virtual-reality and telemedicine approach. J Rehabil Med 2009 Nov;41(12):1016-1102 [FREE Full text] [doi: 10.2340/16501977-0459] [Medline: 19841835]

105. Rand D, Givon N, Weingarden H, Nota A, Zeilig G. Eliciting upper extremity purposeful movements using video games: a comparison with traditional therapy for stroke rehabilitation. Neurorehabil Neural Repair 2014 Oct;28(8):733-739. [doi: 10.1177/1545968314521008] [Medline: 24515927]

106. Sale P, Mazzoleni S, Lombardi V, Galafate D, Massimiani MP, Posteraro F, et al. Recovery of hand function with robot-assisted therapy in acute stroke patients. Int J Rehabil Res 2014;37(3):236-242. [doi: 10.1097/mrr.0000000000000059]

107. Saposnik G, Mamdani M, Bayley M, Thorpe KE, Hall J, Cohen LG, EVREST Steering Committee, EVREST Study Group for the Stroke Outcome Research Canada Working Group. Effectiveness of Virtual Reality Exercises in STroke Rehabilitation (EVREST): rationale, design, and protocol of a pilot randomized clinical trial assessing the Wii gaming system. Int J Stroke 2010 Feb;5(1):47-51 [FREE Full text] [doi: 10.1111/j.1747-4949.2009.00404.x] [Medline: 20088994]

108. Saposnik G, Cohen LG, Mamdani M, Pooyania S, Ploughman M, Cheung D, Stroke Outcomes Research Canada. Efficacy and safety of non-immersive virtual reality exercising in stroke rehabilitation (EVREST): a randomised, multicentre, single-blind, controlled trial. Lancet Neurol 2016 Sep;15(10):1019-1027 [FREE Full text] [doi: 10.1016/S1474-4422(16)30121-1] [Medline: 27365261]

109. Takahashi K, Domen K, Sakamoto T, Toshima M, Otaka Y, Seto M, et al. Efficacy of upper extremity robotic therapy in subacute poststroke hemiplegia: an exploratory randomized trial. Stroke 2016 May;47(5):1385-1388. [doi: 10.1161/STROKEAHA.115.012520] [Medline: 27006452]

110. Timmermans AA, Lemmens RJ, Monfrance M, Geers RP, Bakx W, Smeets RJ, et al. Effects of task-oriented robot training on arm function, activity, and quality of life in chronic stroke patients: a randomized controlled trial. J Neuroeng Rehabil 2014 Mar 31;11:45 [FREE Full text] [doi: 10.1186/1743-0003-11-45] [Medline: 24684808]

111. Tomić TJ, Savić AM, Vidaković AS, Rodić SZ, Isaković MS, Rodríguez-de-Pablo C, et al. ArmAssist robotic system versus matched conventional therapy for poststroke upper limb rehabilitation: a randomized clinical trial. Biomed Res Int 2017;2017:7659893 [FREE Full text] [doi: 10.1155/2017/7659893] [Medline: 28251157]

112. Türkbey TA, Kutlay S, Gök H. Clinical feasibility of Xbox KinectTM training for stroke rehabilitation: a single-blind randomized controlled pilot study. J Rehabil Med 2017 Jan 19;49(1):22-29 [FREE Full text] [doi: 10.2340/16501977-2183] [Medline: 27973678]

113. Vanoglio F, Bernocchi P, Mulè C, Garofali F, Mora C, Taveggia G, et al. Feasibility and efficacy of a robotic device for hand rehabilitation in hemiplegic stroke patients: a randomized pilot controlled study. Clin Rehabil 2017 Mar;31(3):351-360. [doi: 10.1177/0269215516642606] [Medline: 27056250]

114. Volpe BT, Lynch D, Rykman-Berland A, Ferraro M, Galgano M, Hogan N, et al. Intensive sensorimotor arm training mediated by therapist or robot improves hemiparesis in patients with chronic stroke. Neurorehabil Neural Repair 2008;22(3):305-310 [FREE Full text] [doi: 10.1177/1545968307311102] [Medline: 18184932]

115. Wei XJ, Tong KY, Hu XL. The responsiveness and correlation between Fugl-Meyer Assessment, Motor Status Scale, and the Action Research Arm Test in chronic stroke with upper-extremity rehabilitation robotic training. Int J Rehabil Res 2011 Dec;34(4):349-356. [doi: 10.1097/MRR.0b013e32834d330a] [Medline: 22044987]

116. Ang KK, Guan C, Chua K, Ang BT, Kuah C, Wang C, et al. Clinical study of neurorehabilitation in stroke using EEG-based motor imagery brain-computer interface with robotic feedback. Conf Proc IEEE Eng Med Biol Soc 2010;2010:5549-5552. [doi: 10.1109/IEMBS.2010.5626782] [Medline: 21096475]

117. Barker RN, Hayward KS, Carson RG, Lloyd D, Brauer SG. SMART arm training with outcome-triggered electrical stimulation in subacute stroke survivors with severe arm disability: a randomized controlled trial. Neurorehabil Neural Repair 2017 Dec;31(12):1005-1016. [doi: 10.1177/1545968317744276] [Medline: 29199503]

118. Huang Y, Lai WP, Qian Q, Hu X, Tam EW, Zheng Y. Translation of robot-assisted rehabilitation to clinical service: a comparison of the rehabilitation effectiveness of EMG-driven robot hand assisted upper limb training in practical clinical service and in clinical trial with laboratory configuration for chronic stroke. Biomed Eng Online 2018 Jun 25;17(1):91 [FREE Full text] [doi: 10.1186/s12938-018-0516-2] [Medline: 29941043]

119. Hwang $\mathrm{CH}$, Seong JW, Son D. Individual finger synchronized robot-assisted hand rehabilitation in subacute to chronic stroke: a prospective randomized clinical trial of efficacy. Clin Rehabil 2012 Aug;26(8):696-704. [doi: 10.1177/0269215511431473] [Medline: 22261813]

120. Kim H, Miller LM, Fedulow I, Simkins M, Abrams GM, Byl N, et al. Kinematic data analysis for post-stroke patients following bilateral versus unilateral rehabilitation with an upper limb wearable robotic system. IEEE Trans Neural Syst Rehabil Eng 2013 Mar;21(2):153-164. [doi: 10.1109/TNSRE.2012.2207462] [Medline: 22855233] 
121. Liao W, Wu C, Hsieh Y, Lin K, Chang W. Effects of robot-assisted upper limb rehabilitation on daily function and real-world arm activity in patients with chronic stroke: a randomized controlled trial. Clin Rehabil 2012 Feb;26(2):111-120. [doi: 10.1177/0269215511416383] [Medline: 21840917]

122. Page SJ, Hill V, White S. Portable upper extremity robotics is as efficacious as upper extremity rehabilitative therapy: a randomized controlled pilot trial. Clin Rehabil 2013 Jun;27(6):494-503 [FREE Full text] [doi: 10.1177/0269215512464795] [Medline: 23147552]

123. Susanto EA, Tong RK, Ockenfeld C, Ho NS. Efficacy of robot-assisted fingers training in chronic stroke survivors: a pilot randomized-controlled trial. J Neuroeng Rehabil 2015 Apr 25;12:42 [FREE Full text] [doi: 10.1186/s12984-015-0033-5] [Medline: 25906983]

124. Kumar D, Gubbi J, Yan B, Palaniswami M. Motor recovery monitoring in post acute stroke patients using wireless accelerometer and cross-correlation. Conf Proc IEEE Eng Med Biol Soc 2013;2013:6703-6706. [doi:

10.1109/EMBC.2013.6611094] [Medline: 24111281]

125. Bergmann J, Krewer C, Bauer, Koenig A, Riener R, Müller F. Virtual reality to augment robot-assisted gait training in non-ambulatory patients with a subacute stroke: a pilot randomized controlled trial. Eur J Phys Rehabil Med 2018 Jun;54(3):397-407 [FREE Full text] [doi: 10.23736/S1973-9087.17.04735-9] [Medline: 29265791]

126. Cannell J, Jovic E, Rathjen A, Lane K, Tyson AM, Callisaya ML, et al. The efficacy of interactive, motion capture-based rehabilitation on functional outcomes in an inpatient stroke population: a randomized controlled trial. Clin Rehabil 2018 Feb;32(2):191-200 [FREE Full text] [doi: 10.1177/0269215517720790] [Medline: 28719977]

127. Cruz VT, Bento V, Ruano L, Ribeiro DD, Fontão L, Mateus C, et al. Motor task performance under vibratory feedback early poststroke: single center, randomized, cross-over, controlled clinical trial. Sci Rep 2014 Jul 11;4:5670 [FREE Full text] [doi: 10.1038/srep05670] [Medline: 25011667]

128. Lin L, Lin Y, Lin Z, Chuang L, Hsu W, Lin Y. Feasibility and efficacy of wearable devices for upper limb rehabilitation in patients with chronic stroke: a randomized controlled pilot study. Eur J Phys Rehabil Med 2018 Jun;54(3):388-396 [FREE Full text] [doi: 10.23736/S1973-9087.17.04691-3] [Medline: 28627862]

129. Shimodozono M, Noma T, Matsumoto S, Miyata R, Etoh S, Kawahira K. Repetitive facilitative exercise under continuous electrical stimulation for severe arm impairment after sub-acute stroke: a randomized controlled pilot study. Brain Inj 2014;28(2):203-210. [doi: 10.3109/02699052.2013.860472] [Medline: 24304090]

130. Sullivan JE, Hurley D, Hedman LD. Afferent stimulation provided by glove electrode during task-specific arm exercise following stroke. Clin Rehabil 2012 Nov;26(11):1010-1020. [doi: 10.1177/0269215512442915] [Medline: 22561099]

131. Curado MR, Cossio EG, Broetz D, Agostini M, Cho W, Brasil FL, et al. Residual upper arm motor function primes innervation of paretic forearm muscles in chronic stroke after brain-machine interface (BMI) training. PLoS One 2015;10(10):e0140161 [FREE Full text] [doi: 10.1371/journal.pone.0140161] [Medline: 26495971]

132. Lee MM, Cho H, Song CH. The mirror therapy program enhances upper-limb motor recovery and motor function in acute stroke patients. Am J Phys Med Rehabil 2012 Aug;91(8):689-96, quiz 697. [doi: 10.1097/PHM.0b013e31824fa86d] [Medline: 22469877]

133. Chen H, Chen CC, Hsueh I, Huang S, Hsieh C. Test-retest reproducibility and smallest real difference of 5 hand function tests in patients with stroke. Neurorehabil Neural Repair 2009 Jun;23(5):435-440. [doi: 10.1177/1545968308331146] [Medline: 19261767]

134. Lang CE, Edwards DF, Birkenmeier RL, Dromerick AW. Estimating minimal clinically important differences of upper-extremity measures early after stroke. Arch Phys Med Rehabil 2008 Sep;89(9):1693-1700 [FREE Full text] [doi: 10.1016/j.apmr.2008.02.022] [Medline: 18760153]

135. Hsieh Y, Wang C, Wu S, Chen P, Sheu C, Hsieh C. Establishing the minimal clinically important difference of the Barthel Index in stroke patients. Neurorehabil Neural Repair 2007;21(3):233-238. [doi: 10.1177/1545968306294729] [Medline: 17351082]

136. AbilityLab Home | Shirley Ryan AbilityLab. 2019. Rivermead Motor Assessment. URL: https://www.sralab.org/ rehabilitation-measures/rivermead-motor-assessment [accessed 2019-09-23]

137. AbilityLab Home | Shirley Ryan AbilityLab. 2019. Chedoke Arm and Hand Activity Inventory. URL: https://www.sralab.org/ rehabilitation-measures/chedoke-arm-and-hand-activity-inventory-7 [accessed 2019-09-23]

138. Dixon D, Johnston M, McQueen M, Court-Brown C. The Disabilities of the Arm, Shoulder and Hand Questionnaire (DASH) can measure the impairment, activity limitations and participation restriction constructs from the International Classification of Functioning, Disability and Health (ICF). BMC Musculoskelet Disord 2008 Aug 20;9:114 [FREE Full text] [doi: 10.1186/1471-2474-9-114] [Medline: 18715495]

139. Franchignoni F, Vercelli S, Giordano A, Sartorio F, Bravini E, Ferriero G. Minimal clinically important difference of the disabilities of the arm, shoulder and hand outcome measure (DASH) and its shortened version (QuickDASH). J Orthop Sports Phys Ther 2014 Jan;44(1):30-39. [doi: 10.2519/jospt.2014.4893] [Medline: 24175606]

140. Fulk GD, Ludwig M, Dunning K, Golden S, Boyne P, West T. How much change in the stroke impact scale-16 is important to people who have experienced a stroke? Top Stroke Rehabil 2010;17(6):477-483. [doi: 10.1310/tsr1706-477] [Medline: 21239371] 
141. Cameirão M, Badia S, Duarte E, Verschure PF. Virtual reality based rehabilitation speeds up functional recovery of the upper extremities after stroke: a randomized controlled pilot study in the acute phase of stroke using the rehabilitation gaming system. Restor Neurol Neurosci 2011;29(5):287-298. [doi: 10.3233/RNN-2011-0599] [Medline: 21697589]

142. Nijenhuis SM, Prange-Lasonder GB, Stienen AH, Rietman JS, Buurke JH. Effects of training with a passive hand orthosis and games at home in chronic stroke: a pilot randomised controlled trial. Clin Rehabil 2017 Feb;31(2):207-216. [doi: 10.1177/0269215516629722] [Medline: 26869596]

143. Lannin NA, Cusick A, Hills C, Kinnear B, Vogel K, Matthews K, et al. Upper limb motor training using a Saebo orthosis is feasible for increasing task-specific practice in hospital after stroke. Aust Occup Ther J 2016 Dec;63(6):364-372. [doi: 10.1111/1440-1630.12330] [Medline: 27646624]

144. Wolf SL, Sahu K, Bay RC, Buchanan S, Reiss A, Linder S, et al. The HAAPI (Home Arm Assistance Progression Initiative) Trial: a novel robotics delivery approach in stroke rehabilitation. Neurorehabil Neural Repair 2015;29(10):958-968 [FREE Full text] [doi: 10.1177/1545968315575612] [Medline: 25782693]

145. Alon G, Levitt AF, McCarthy PA. Functional electrical stimulation (FES) may modify the poor prognosis of stroke survivors with severe motor loss of the upper extremity: a preliminary study. Am J Phys Med Rehabil 2008 Aug;87(8):627-636. [doi: 10.1097/PHM.0b013e31817fabc1] [Medline: 18645322]

146. Yuzer GF, Dönmez B, Özgirgin N. A randomized controlled study: effectiveness of functional electrical stimulation on wrist and finger flexor spasticity in hemiplegia. J Stroke Cerebrovasc Dis 2017 Jul;26(7):1467-1471. [doi: 10.1016/j.jstrokecerebrovasdis.2017.03.011] [Medline: 28462794]

147. Villafañe JH, Taveggia G, Galeri S, Bissolotti L, Mullè C, Imperio G, et al. Efficacy of short-term robot-assisted rehabilitation in patients with hand paralysis after stroke: a randomized clinical trial. Hand (N Y) 2018 Jan;13(1):95-102 [FREE Full text] [doi: 10.1177/1558944717692096] [Medline: 28719996]

148. Friedman N, Chan V, Reinkensmeyer AN, Beroukhim A, Zambrano GJ, Bachman M, et al. Retraining and assessing hand movement after stroke using the MusicGlove: comparison with conventional hand therapy and isometric grip training. $\mathrm{J}$ Neuroeng Rehabil 2014 Apr 30;11:76 [FREE Full text] [doi: 10.1186/1743-0003-11-76] [Medline: 24885076]

149. Prange-Lasonder G, Radder B, Kottink AI, Melendez-Calderon A, Buurke J, Rietman J. Applying a soft-robotic glove as assistive device and training tool with games to support hand function after stroke: Preliminary results on feasibility and potential clinical impact. IEEE Int Conf Rehabil Robot 2017 Jul;2017:1401-1406. [doi: 10.1109/ICORR.2017.8009444] [Medline: 28814016]

150. Barry JG, Ross SA, Woehrle J. Therapy incorporating a dynamic wrist-hand orthosis versus manual assistance in chronic stroke: a pilot study. J Neurol Phys Ther 2012 Mar;36(1):17-24. [doi: 10.1097/NPT.0b013e318246203e] [Medline: 22354108]

151. Knutson JS, Gunzler DD, Wilson RD, Chae J. Contralaterally controlled functional electrical stimulation improves hand dexterity in chronic hemiparesis: a randomized trial. Stroke 2016 Oct;47(10):2596-2602 [FREE Full text] [doi: 10.1161/STROKEAHA.116.013791] [Medline: 27608819]

152. Cramer SC. Repairing the human brain after stroke: I. Mechanisms of spontaneous recovery. Ann Neurol 2008 Mar;63(3):272-287. [doi: 10.1002/ana.21393] [Medline: 18383072]

153. Church G, Parker J, Powell L, Mawson S. The effectiveness of group exercise for improving activity and participation in adult stroke survivors: a systematic review. Physiotherapy 2019 Jan 19. [doi: 10.1016/j.physio.2019.01.005] [Medline: 31003848]

154. Stroke Association. 2017. State of the Nation: Stroke Statistics. URL: https://www.stroke.org.uk/resources/ state-nation-stroke-statistics [accessed 2019-11-07]

155. Beaton DE, Boers M, Wells GA. Many faces of the minimal clinically important difference (MCID): a literature review and directions for future research. Curr Opin Rheumatol 2002 Mar;14(2):109-114. [doi: 10.1097/00002281-200203000-00006] [Medline: 11845014]

156. Akobeng AK. Understanding randomised controlled trials. Arch Dis Child 2005 Aug;90(8):840-844 [FREE Full text] [doi: 10.1136/adc.2004.058222] [Medline: 16040885 ]

157. Bonell C, Fletcher A, Morton M, Lorenc T, Moore L. Realist randomised controlled trials: a new approach to evaluating complex public health interventions. Soc Sci Med 2012 Dec;75(12):2299-2306. [doi: 10.1016/j.socscimed.2012.08.032] [Medline: 22989491]

158. Pawson R, Tilley N. Realistic Evaluation. Thousand Oaks, CA: Sage; 1997.

159. Moore G. Cramming more components onto integrated circuits. Proc IEEE 1998;86(1):82-85. [doi: 10.1109/jproc.1998.658762]

160. National Institute of Health and Care Excellence (NICE). 2019. Evidence standards framework for digital health technologies. URL: https://www.nice.org.uk/about/what-we-do/our-programmes/ evidence-standards-framework-for-digital-health-technologies [accessed 2019-11-07]

\section{Abbreviations \\ ARAT: Action Research Arm Test \\ BBT: Box and Blocks Test}


BI: Barthel Index

CAHAI: Chedoke Arm and Hand Activity Inventory

CRoB: Cochrane Risk of Bias

DHTs: Digital Health Technologies

FES: functional electrical stimulation

ICF: International Classification of Functioning, Disability, and Health

ICT: information and communication technology

JTHFT: Jebsen-Taylor Hand Function Test

MAL: Motor Activity Log

MAS: Motor Assessment Scale

MCID: minimally clinically important difference

MeSH: Medical Subject Headings

NIHR: National Institute for Health Research

QuickDASH: short version of disabilities of arm, shoulder, and hand

RCT: randomized controlled trial

RMA: Rivermead Motor Assessment

SIS: Stroke Impact Scale

UEFT: Upper Extremity Function Test

UL: upper limb

WHO: World Health Organization

WMFT: Wolf Motor Function Test

\author{
Edited by G Eysenbach; submitted 03.09.19; peer-reviewed by I Cikajlo, E Sadeghi-Demneh, H Rostami, X Lu, F Lanfranchi, S \\ Haghayegh; comments to author 28.09.19; revised version received 16.10.19; accepted 22.10.19; published 08.01.20 \\ Please cite as: \\ Parker J, Powell L, Mawson S \\ Effectiveness of Upper Limb Wearable Technology for Improving Activity and Participation in Adult Stroke Survivors: Systematic \\ Review \\ J Med Internet Res 2020;22(1):e15981 \\ URL: https://www.jmir.org/2020/1/e15981 \\ doi: $10.2196 / 15981$ \\ PMID: 31913131
}

C Jack Amy Parker, Lauren Powell, Susan Mawson. Originally published in the Journal of Medical Internet Research (http://www.jmir.org), 08.01.2020. This is an open-access article distributed under the terms of the Creative Commons Attribution License (https://creativecommons.org/licenses/by/4.0/), which permits unrestricted use, distribution, and reproduction in any medium, provided the original work, first published in the Journal of Medical Internet Research, is properly cited. The complete bibliographic information, a link to the original publication on http://www.jmir.org/, as well as this copyright and license information must be included. 